\title{
Lessons learned from the first years with the NetzDG
}

\author{
Maximilian Hemmert-Halswick
}

Abstract: German lawmakers have done pioneering work with the Network Enforcement Act. This law makes specific compliance requirements for social networks in order for them to remove illegal content more quickly and reliably. Criticism was particularly strong at the beginning, but the law now seems to have taken its place in the field of platform regulation. Three years after its enactment, the law underwent an amendment process. The amendment is based primarily on the experience gained up to that point. In essence, the aim is to eliminate identified deficiencies, which is mainly achieved by extending user rights and tighter regulatory control.

Keywords: Content Regulation; Hate Speech; Social Networks; Overblocking; Compliance approach; Censorship

\section{Introduction - Balance between State Sovereignty and Economic Freedom}

"[A]s Nostradamus said: across the sea they will come like locusts, but they will not be animals... how right the man was...". This comment refers to the refugee crisis in Germany and reveals the author's displeasure or contempt for the policy and the people who have fled. Are the confines of civilized, permissible discourse being left behind here? This is certainly not a simple question. The court that had to rule on this also had a hard time with the decision, but ruled that the deletion of the content was lawful. ${ }^{1}$

When it comes to the legally mandated deletion of content on social networks, such cases inevitably take center stage. There will hardly be any discussion about extreme, blatant cases, i.e. where there is broad consensus that such social interaction is unacceptable. Think, for example, of a call to commit murder; or even dishonorable and false allegations about other people that can seriously damage the person. In contrast, borderline cases show the difficulty of the matter. One must be aware of this, and it is

1 OLG Stuttgart, 6.9.2018-4 W 63/18. 
against this background that the German "Law to Improve Law Enforcement in Social Networks" - in short: NetzDG ${ }^{2}$ - must be seen. The law was passed just under 4 years ago. The aim is to protect public safety, in particular the general right to protection of one' s personality, and to ensure rational discourse. To this end, it requires providers of social networks to delete unlawful comments more quickly and reliably. ${ }^{3}$ In 2020 , the legislator began the process for amending the NetzDG. With three years of experience applying the law, it is hoped to address some shortcomings and provide improved enforcement. A year later, the amendments were approved by all legislative bodies.

This chapter will present the beginnings and the experiences that have led to the amendments of the NetzDG. The lines of development clearly speak for a learning effect on the part of the German legislator, which is also likely to be of international interest, since parallels can also be found in other countries, even if they have not rushed ahead with a law like the NetzDG. However, a great deal has happened in the industry during this time: content regulation has often been in the media spotlight; Twitter has blocked accounts of highly public figures ${ }^{4}$, and Facebook has set up an "Oversight Board" which serves as a quasi-court. Against the backdrop of these events, the tendency can probably be discerned that it has now become clear that states must become involved in content regulation in one way or another.

\section{The Approach of the NetzDG}

The law was the first of its kind worldwide. It was subject to harsh criticism, especially during the legislative process. ${ }^{5}$ Yet, a modus vivendi seems

2 Netzwerkdurchsetzungsgesetz, September 1, 2017 (BGBl. I S. 3352).

3 Cf. BT-Drs. 18/12356, 11 (German Parliament Document).

4 The most noted case was certainly the blocking of the account of then-President Donald Trump in response to the storming of the Capitol, and later, for example, of Mike Lindell ("MyPillow Guy") for spreading disinformation concerning the results of the 2020 presidential election.

5 Spindler, Gerald, "Der Regierungsentwurf zum Netzwerkdurchsetzungsgesetz europarechtswidrig?", Zeitschrift für Urheber- und Medienrecht ZUM (2017): 473; Gersdorf, Hubertus, "Hate Speech in sozialen Netzwerken," MMR Zeitschrift für IT-Recht und Recht der Digitalisierung (2017): 439. Guggenberger, Nikolas, "Das Netzwerkdurchsetzungsgesetz - schön gedacht, schlecht gemacht, “ Zeitschrift für Rechtspolitik ZRP (2017): 98. 
to have been found now. While the law was described as "innovative"6 on the one hand, criticism was also voiced that the law constituted a violation of freedom of expression. In the following, the approach of the law will be described, and the points of criticism will be explained and put into context.

\section{Compliance approach}

The law has a compliance approach, which means that it just wants to make sure that the social networks act according to the law, and it does not - at least directly - address the users in any way.

The regulatory approach of the NetzDG is to make social network providers comply to a greater extent with their deletion obligations, which existed already without the NetzDG. In this respect, the NetzDG sets compliance requirements for how social network providers are to set up their complaint management, i.e. how they are supposed to deal with user complaints. Among other things, it is supposed to guarantee the deletion of illegal content within seven days or - if the illegality is "obvious" within 24 hours. This focus on time constraints resulted from previous experience, as high-ranking politicians, among others, had been victims of online aggression and the content was not deleted for several days despite complaints. Subsequently, the German government determined in surveys that the social networks in fact only very rarely comply with their deletion obligations. ${ }^{7}$ This deficiency is therefore to be remedied by setting specific time limits.

In this approach, it is of course noticeable that the network providers take on the active role; ultimately, they are the ones who decide which content will be deleted. The state retreats to a position of an observer. Criticism was voiced during the legislative process that law enforcement was being "privatized". ${ }^{8}$ However, this criticism does not really hold up, since the NetzDG also emphasizes that network operators do not have any active monitoring obligations. One alternative, of course, is for the state

6 Holznagel, Bernd, "Das Compliance-System des Entwurfs des Netzwerkdurchsetzungsgesetzes, “ Zeitschrift für Urheber- und Medienrecht ZUM (2017): 615; Bundestag Protokoll-Nr. 18/153, 21.

7 BT-Drs. 18/12356, 11.

8 Wimmers, Jörg and Heymann, Britta, "Zum Referentenentwurf eines Netzwerkdurchsetzungsgesetzes (NetzDG) - eine kritische Stellungnahme, “ AfP Zeitschrift für das gesamte Medienrecht (2017): 98. 
to take over monitoring. Conversely, there is the option of not imposing strict requirements on network operators. With the compliance approach, the German legislator wants to strike a balance between a too far-reaching encroachment on corporate freedom and an ineffective regulatory regime.

\section{Terminology}

Just as in any law, it is of particular importance to define the essential terms in order to ensure its applicability in the first place. In many areas of law, reference can be made to familiar terms (that are already in use (in other laws). In the case of the NetzDG, this applies only to a limited extent, since content regulation on social networks is practically a new phenomenon. First and foremost, the definitions must clarify what social networks are and what content is to be covered by the NetzDG.

\section{a) Addressees: social networks}

Regarding the term "social network", perhaps the "you know it when you see it"-approach would be a viable option, especially for younger Internet users who have a more or less clear idea of what is meant by a social network without ever having taken a closer look at the individual criteria. Ultimately, the question of definition is related to what the NetzDG is intended to achieve. The legislator was primarily concerned with the perpetuation effect associated with publication on a network used by many people. The fact that only the big ones are to be covered means that various parameters have to be set in a way to exclude the smaller ones. The number of members plays a role - but does it only depend on registered users? What about messenger services, where the groups can sometimes be so large that they resemble "classic" social networks? What about comment functions on ,for example, newspaper sites? In order not to cover these aspects, the German legislator has chosen the following definition:

"Telemedia service providers who operate platforms on the Internet with the intention of making a profit, which are intended for users to share any content with other users or make it accessible to the public." 9 Thematically limited social networks such as Linkedin are excluded by the arbitrariness criterion ("to share any content"). Furthermore, only

$9 \$ 1$ sec. 1 NetzDG. 
networks with a user base of more than 2 million users are included. Journalistic content is excluded. Gated communities such as messenger services are also explicitly excluded, as this is not directly clear from the definition. ${ }^{10}$

\section{b) The most important term: illegal content}

One of the most important points to consider when passing a law that targets content on social networks is what content is covered. What content is at issue in the first place? What content is so important or harmful that it should be removed from the platform as quickly as possible. If the guidelines are too far-reaching, the accusation of censorship can legitimately be made. However, if too few specifications are made, the effectiveness can be questioned and the scope of application will be relatively small. In addition, the delimitation of content must be as precise as possible so that it is clear which content is covered - so that, on the one hand, network providers know which content is to be deleted. On the other hand, it is just as important for users to know what they are allowed to post.

According to the NetzDG, illegal content is content that fulfills one of the criminal offenses listed in $\$ 1$ of the NetzDG, which are primarily those that roughly cover the phenomenon of "hate speech," i.e., the crimes of defamation and the crimes against public order such as incitement to hatred. The fact that the NetzDG is limited to criminal offenses makes it clear that only relatively vile statements are covered by it, although it goes without saying that difficulties of demarcation cannot be avoided here either. However, by this the legislator avoids defining the term hate speech or disinformation, as this is hardly possible. ${ }^{11}$ The criminal offense of "insult" is included in the NetzDG. This is, of course, also an offense that is open to interpretation, and in this respect is similarly vague as the term hate speech. Social networks, on the other hand, define hate speech and disinformation in their guidelines, but can do so comparatively easily because, unlike democratically constituted states, they - generally speaking do not have to meet balanced legal requirements. Here, however, it also

10 BT-Drs. 18/12356, 12 (German Parliament Document).

11 Hoven, Elisa and Krause, Melena, "Die Strafbarkeit der Verbreitung von ,Fake News',"Juristische Schulung (JuS) (2017): 1167. 
becomes obvious that the question of definitional sovereignty is of utmost importance. $^{12}$

\section{Complaints management}

\section{a) Establishment of a complaint management system}

The most important element is that the social networks must implement a proper complaints management system as outlined in $\$ 3$ NetzDG: a functional system of how they handle the complaints against hate speech content. The submission of complaints must be as simple as possible. Ideally, the complaint option is set up directly next to the post in the news feed. It must then be ensured that the network provider takes note of the complaint quickly. This is then followed by an assessment within the appropriate deletion period. Setting up a complaints management system also involves providing regular training for employees to ensure that they are up to the task; it has been found ot that the task of deleting illegal content is very stressful.

12 The subject of a current debate is whether network providers may also delete content if the content is not constitutionally objectionable. This has to do with the indirect third-party effect of fundamental rights that exists in Germany. This means that under certain circumstances, private parties such as big companies must also comply with fundamental rights requirements in their actions. In relation to the case of content regulation on social networks, this means that Facebook and Co. must respect users' freedom of expression. However, the extent to which they must respect users' fundamental rights has not yet been conclusively decided. The answer is particularly relevant to the question of whether network providers may also delete lawful content. If there is a strong connection to fundamental rights, this is likely to be negated. 
Illustrative diagram of the complaints management system, according to $\$ 3$ NetzDG:

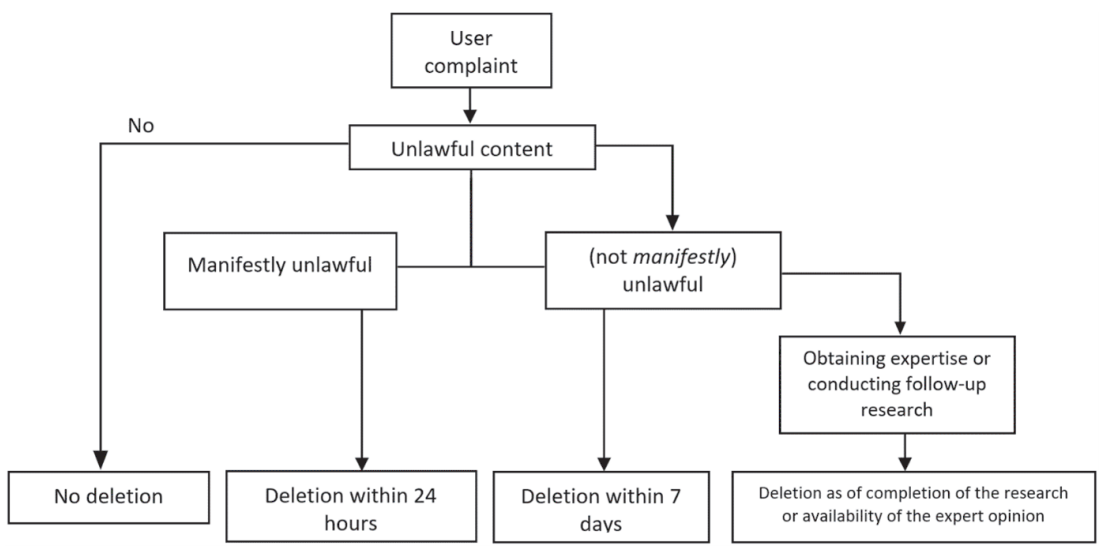

\section{b) The Danger of Overblocking}

The main goal of the NetzDG is that the networks get illegal content quickly off their platforms. However, since a fine can be imposed for violations of the NetzDG, there is a risk that the networks will, in case of doubt, delete content rather than leave it on the platform. The consequence of this situation might be an overblocking. That was the main critique by the experts during the legislative hearing. ${ }^{13}$ The hope was that an assessment of whether there really was overblocking could be made on the basis of the transparency reports that providers were required to produce under $₫ 2$ of the NetzDG. Unsurprisingly, however, the transparency reports hardly allowed any conclusions to be drawn in this regard. The bare figures on complaints received and deletions made say practically nothing about the

13 Cf. protocol of the parliamentary expert hearing protocol Nr. 18/153, 16, 30, 38; Guggenberger, Nikolas, "Das Netzwerkdurchsetzungsgesetz in der Anwendung, "TRENNUNG Neue Juristische Wochenschrift (NJW) (2017): 2577; Schwartmann, Rolf, "Verantwortlichkeit Sozialer Netzwerke nach dem Netzwerkdurchsetzungsgesetz,"TRENNUNG GRUR-Prax Praxis im Immaterialgüter- und Wettbewerbsrecht (2017): 317. 
existance of overblocking. ${ }^{14}$ However, a recent study has come to the conclusion that overblocking is taking place. ${ }^{15}$

Closely related to this is the accusation of insufficient consideration of the interests of the authors of deleted posts. In principle, the NetzDG does not provide for the author to be heard at any point in the proceedings or to obtain a reversal of the deletion. There may be various reasons for not involving the author, for example because this would prolong the proceedings. After all, expeditiousness in cancellation is the key purpose of the law. A possible starting point is the establishment of an option for the author to complain after the deletion.

\section{c) Establishment of regulated self-regulation}

In response to this criticism, which was voiced during the legislative process, another mechanism was introduced to ensure the accuracy of the decisions on the one hand and to take the pressure off the social network providers on the other. To this end, in $\$ 3$ sec. 6-9 NetzDG, the option was created for the social networks themselves to establish independent bodies to review complaints on behalf of the social networks: establishment of regulated self-regulation. ${ }^{16}$ The first and most prominent of its kind is the Freiwillige Selbstkontrolle Multimedia-Dienste $\left(\mathrm{FSM}^{17}\right)$. The social networks can therefore then always decide whether to forward a complaint to this body. They must then accept the decision of this body and make a deletion accordingly. This regulation has existed from the beginning, but the first trials were not carried out until 2020 , as the establishment of the body had taken some time. ${ }^{18}$

14 Löber, Lena Isabell and Roßnagel, Alexander, "Das Netzwerkdurchsetzungsgesetz in der Umsetzung," $M M R$ (2019): 73; Ladeur, Karl-Heinz, "Ist der Regierungsentwurf eines NetzDG 2.0 vom 19.2.2020 netzgerecht?", Kommunikation und Recht $K \mho R$ (2020): 250; Heindorf, Manon, „Das Netzwerkdurchsetzungsgesetz in der Umsetzung: Zwei Jahre NetzDG - eine Bilanz, "Verwaltungsrundschau VR (2020): 117.

15 Liesching, Marc, et al., Das NetzDG in der praktischen Anwendung (Berlin: Carl Grossmann Verlag, 2021), 143, doi:10.24921/2021.94115953.

16 This is modeled after voluntary monitoring in the film industry (Freiwillige Selbstkontrolle der Filmwirtschaft).

17 In English: Association for Voluntary Self-Regulation of Digital Media Service Providers.

18 See chapter in this book Holznagel/Kalbhenn. 
Illustrative diagram of the process with the FSM ${ }^{19}$ :

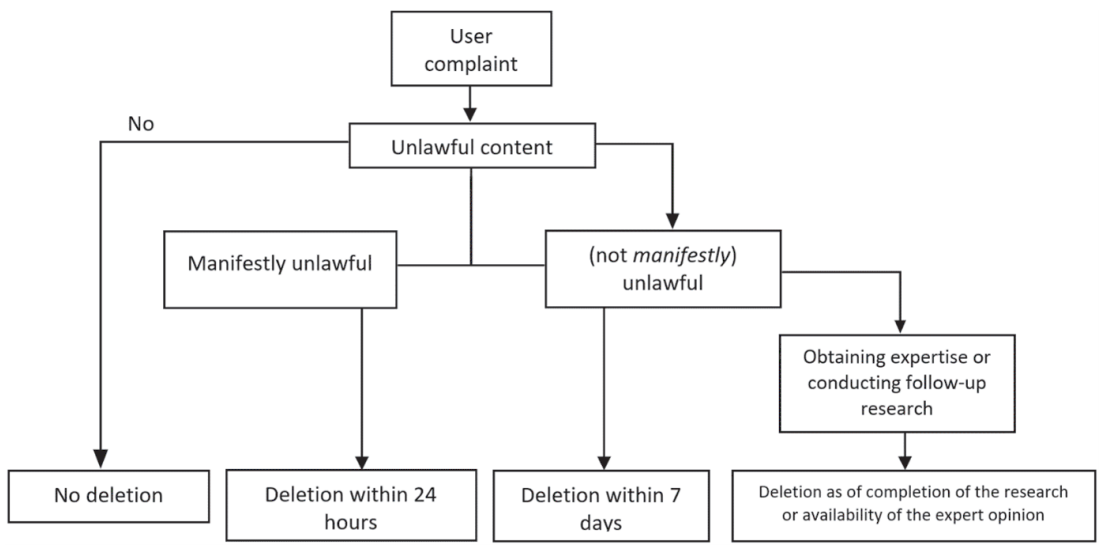

\section{Transparency obligations: Conflict between NetzDG and community} standards - Facebook case study

As already mentioned, the obligations of the NetzDG apply primarily to the network providers. They have to set up complaint management, they have to check the content, and they have to carry out deletions if necessary. State authorities stay out of this practice. However, since the state does not want to leave the network providers to act idly and unsuspectingly, the NetzDG provides for comprehensive transparency obligations. Network providers must report on how they implement the requirements of the NetzDG. In terms of the role of the state in the structure of the NetzDG, this is the most important regulation, so that the state does not completely relinquish responsibility. The transparency obligations provide the state and the public with information about how many deletions are made, how many complaints are received by the networks, and what type of content the complaints focus on. It should be mentioned that the transparency reports essentially only provide quantitative information on how complaints are handled. In qualitative terms, the network operators only have to describe how they have structured their complaints management and what they base their decisions on. Examples of deletions are - unfortunately not to be included in the transparency reports.

19 On the basis of the diagram at "NetzDG," FSM, accessed July 6, 2021, https://ww w.fsm.de/de/netzdg. 
It is particularly noteworthy that Facebook - i.e. the largest social network - is attempting to circumvent the transparency obligation by setting up two complaints procedures. One is the NetzDG complaint procedure, which is very hidden and can only be reached via several clicks. The other is Facebook's own complaint procedure, which is based on Facebook's community standards and is located directly next to a post. Facebook does not list any information about the latter complaint procedure in the transparency report, although the vast majority of complaints are made via this procedure: approximately 2,000 complaints are listed in the NetzDG Transparency Report ${ }^{20}$, whereas several million complaints are counted with regard to the Community Standards, albeit globally. ${ }^{21}$ The Federal Office of Justice has imposed a fine of two million euros on Facebook for this. The courts are currently reviewing whether this was lawful. It is not clear what the answer will be, because the NetzDG only stipulates transparency obligations in relation to the NetzDG complaints procedure. Rather, the legislator had probably not even considered this as an option, and had simply assumed that the network providers would report on any deletions. However, it is also clear that Facebook's approach is a deliberate circumvention of the law. On the other hand, it may not always be so easy for the social networks to determine exactly whether a complaint is applicable to German law.

\section{Conclusion}

So far, the basic requirements of the NetzDG have been presented. It became clear that there was potential for improvement. For example, the danger of overblocking could be further mitigated with a counter-appeal procedure, in which the person affected by the deletion also presents his or her point of view. Also, the users had little say in the matter. However, the lack of inclusion of network-internal complaints was an obvious shortcoming. It was also stated that the legislator had simply not thought of this and subsequently realized that the NetzDG should also include these com-

20 “NetzDG Transparenzbericht Januar 2021,” Facebook, accessed July 6, 2021, https://about.fb.com/de/wp-content/uploads/sites/10/2021/01/Facebook-Netz DG-Transparenzbericht-Januar-2021.pdf (July-December 2020: 4.211 complaints, $29 \%$ deleted).

21 "Community Standards Enforcement Report, Third Quarter 2020," Facebook, accessed July 6, 2021, https://about.fb.com/news/2020/11/community-standards-enf orcement-report-nov-2020/ (22 Mio. regarding hate speech, 95\% deleted). 
plaints. The fact that there is a fundamental misunderstanding is also clear from the fact that in the Summer of 2019, the Federal Minister of Justice, Christine Lambrecht, had to make clear that the community standards of the networks are "not above the law". ${ }^{2}$

\section{Amending the NetzDG}

Three things can be identified that fueled the amendment process: First, the lawmaker still want to make sure that there is no overblocking ocurring. Secondly, they want to know about the complaints handling in more detail, as in enhance the transparency of deletion decisions. And thirdly, the power struggle in which the state wants to be in control of the rules that govern online speech. The new provisions that address these findings are presented below.

\section{Countercomplaints procedure}

The countercomplaints procedure, which is introduced in the new $₫ 3 \mathrm{~b}$ of the NetzDG, obliges the providers of social networks to have a procedure in place that allows users to state their opinion on a decision made by the provider and to seek a re-examination. Both the author of a content and the complaining user can take the initiative. According to the new provision, the provider must "promptly subject its initial decision to reconsideration by a person not involved with the initial decision." Only if the provider wishes to remedy the objection the other party must be given the opportunity to state its position; in this way the new law takes into account that objections can also be raised abusively. The procedure ends with the review decision, which must be forwarded to the two users concerned.

With this, the legislator wants to address the criticism regarding overblocking and the lack of procedural participation of the author. Too much deletion is to be prevented by allowing the authors of content to take action against deletions in an internal network procedure. Conversely,

22 "Bundesamt für Justiz (Bfj) erlässt Bußgeldbescheid gegen Facebook," Federal Ministry of Justice and Consumer Protection, Press release from July 3, 2019, accessed July 6, 2021, https://www.bmjv.de/SharedDocs/Artikel/DE/2019/070319_ Facebook.html. 
it should be easier to have a review of content that has been objected to by users but not removed.

The countercomplaints procedure is in particular a response to the widespread called for a "put-back procedure". ${ }^{23}$ However, the law precisely does not stipulate the right to reinstatement of the unlawfully deleted content. Indeed, it does not say anything about what is to be done after the provider's repeated decision. Presumably, the lawmaker implicitly assumes that this will lead to a put-back, in case of the lawfulness of the previously deleted content. For example, at one point the explanatory memorandum talks about the provider reporting "in how many cases the counterproposal was remedied." 24 It is difficult to imagine a remedy that does not involve a put-back.

It has been argued in the literature that the legislator is reluctant to establish an explicit put-back procedure, as this would entail a right to publication. Whether such a right could be upheld constitutionally is still being debated. In this respect, the legislative reluctance can be explained by the legal situation, which is still developing.

Another criticism goes against the timing of the countercomplaints procedure, or rather that the author of a deleted content must first accept the deletion; he or she is not heard before the deletion. It is argued here that the protection of freedom of expression requires that the author be heard beforehand and given the opportunity to respond to the complaint. The "Stadium Ban Decision" of the Federal Constitutional Court is being referenced for this argument. ${ }^{25}$ In this case, the court suggests that a hearing be held prior to the exclusion of a socially significant event (attending a football match). ${ }^{26}$ Facebook and other social networks are - in a way - comparable to visiting a football stadium in terms of social relevance... yet it does not seem necessary to require a pre-removal cross-appeal on constitutional grounds: Deleting a piece of content is not comparable to an exclusion - blocking the account would be - furthermore, not removing an unlawful piece of content weighs heavier than removing a lawful piece of content (that is, especially, if the countercomplaints procedure can ensure a speedy restoration).

23 Löber, and Roßnagel, "Das Netzwerkdurchsetzungsgesetz," 75; Peukert, Alexander, "Gewährleistung der Meinungs- und Informationsfreiheit in sozialen Netzwerken," MMR (2018): 572; Schwartmann,"Verantwortlichkeit sozialer Netzwerke, " 318.

24 BT-Drs. 19/18792, 8 ( $\$ 2$ (2) No. 11).

25 Niggemann, Sandra, "Die NetzDG-Novelle," Computer und Recht CR (2020): 329.

BVerfGE 148, 267. 


\section{Transparency rules}

Since shortcomings in the transparency regulations also became apparent relatively quickly, the legislator had to take action here as well. In particular, the circumvention by Facebook was a deficiency with an easy remedy. Here, the bill on combating right-wing extremism and hate crime brings about the most significant innovation. Therein it is regulated that, for example, complaints and deletions in connection with the Community Directives are also listed in the transparency report. This is achieved by broadening the definition of "complaints" to now include complaints under the Community Standards. This certainly makes sense, as do the stricter requirements for user-friendliness of reporting channels included in the amendment. A dichotomy of reporting channels, as explained at the beginning with regard to Facebook, should then no longer exist.

The amendment expands the reporting obligations, requiring reporting on the use of procedures for automated detection of illegal content. And also on whether and to what extent academia has been given access to information from the network provider to enable evaluation.

These additions are all reasonable, but the decision-making practice of the network providers should be even more transparent. All decisions about content should be published, as some have already pointed out. ${ }^{27}$ As a response to this criticism, the legislature added another amendment "at the last minute". ${ }^{28} \$ 5$ a now gives "researchers" a right to access information from social network providers about "the use and specific mode of operation of procedures for the automated recognition of content" as well as "the circulation of content which has been the subject of complaints about illegal content or which has been removed or blocked by the provider". The scope of those entitled to make a claim extends to "any ... person conducting scientific research" (paragraph 1). An excessive level of claims will be prevented by the fact that a concept for the protection of the data received must be submitted to both the network provider and the supervisory authority along with the claim. In addition, the right to information will be mitigated by giving the provider grounds for refusing to provide information ("if his interests worthy of protection significantly outweigh the public interest in the research"). One obstacle to asserting the claim may

27 Eifert, Martin, "Rechenschaftspflichten für soziale Netzwerke und Suchmaschinen,“ Neue Juristische Wochenschrift (NJW) 2017: 1453; Löber, and Roßnagel, "Das Netzwerkdurchsetzungsgesetz, “ 75.

28 BT-Drs. 19/29392 (German Parliament Document). 
also be that the network provider is entitled to reimbursement for the costs incurred in providing the information; as a general rule, the law limits the reimbursement costs to EUR 5,000.

\section{Regulatory supervision}

\section{a) Powers of intervention}

$\$ 4 \mathrm{a}$ introduces a new supervisory regime. According to this, the Federal Office of Justice monitors compliance with the provisions of the NetzDG. From now on, this agency can take the necessary measures against providers in the event of violations of the NetzDG. Previously, the agency could only take repressive action in the form of fines. With its supervisory authority, the Federal Office of Justice can impose a forward-looking obligation on providers to put an end to a violation of the NetzDG without having to initiate fine proceedings.

The more flexible and constructive form of regulatory supervision now impleemented is to be welcomed. The threat of fines - one of the main points of criticism of the NetzDG - will thus lose its intimidating effect.

\section{b) Duty to cooperate - Duty to report}

A provision contained in the amendment that obliges network providers to report certain content to the law enforcement authorities has been met with much skepticism. This obligation applies to certain criminal offenses enlisted in $\mathbb{1} 1 \mathrm{NetzDG}$; this involves relatively serious offenses in whose prosecution there is a great interest, such as incitement to hatred, the formation of terrorist organizations, or the preparation of a serious act of violence that endangers the state. The idea is that law enforcement agencies will no longer be able to keep track of all the crimes committed on the Internet. Legislators hope that this will not only improve law enforcement, but also have a deterrent effect on users.

In the first draft, the procedure was designed in such a way that the network providers report such content to the Federal Criminal Police Office (Bundeskriminalamt); the IP address and port number are also reported; the Federal Criminal Police Office then assesses whether the content is actually relevant to criminal law. If the answer is affirmative, the full data identifying the person is requested from the social network. The 
data is then forwarded to the law enforcement authorities by the Federal Criminal Police Office. There has been much criticism of this regulation. An expert opinion from the Bundestag's academic service pointed to data protection concerns. ${ }^{29}$ Another expert opinion commissioned by the Green Party pointed to problems with regard to the timing of the data transfer. According to the opinion, the Federal Constitutional Court had only shortly before ruled that content should not be transmitted at the same time as the traffic data. ${ }^{30}$ The legislative package was therefore not signed by the President (as the final required legislative act). In February 2021, the bill was updated ${ }^{31}$ and approved a few month later ${ }^{32}$.

Furthermore, this new regulation is also criticized for promoting the "privatization" of law enforcement. ${ }^{33}$ It would practically make the social networks responsible for law enforcement. Of course, it cannot be denied that the social networks decide which content they forward to the Federal Criminal Police Office and which they do not. However, it must be seen that ultimately only the social networks are in a position to comprehensively monitor the content and install a comprehensive complaints management system, which makes them aware of the damaging content. In this respect, the entire problem of content regulation can be illustrated with the following: The state wants to, but cannot - the social networks can, but do not want to. Of course, the latter is only true as long as it is not financially profitable, but state paternalism is probably always an evil for businesses such as social networks.

29 Scientific service of the Bundestag, "Die Vereinbarkeit der Meldepflicht nach $₫ 3 a$ Abs. 4 NetzDG n.F. mit dem Recht der Sitzländer der Anbieter von sozialen Netzwerken und das Verhältnis der verschiedenen Einrichtungen der Entscheidungskontrolle nach NetzDG und JMStV, “ September 11, 2020 Document No. WD 10 - 3000 - 043/20.

30 Bäcker, Matthias, "Folgerungen aus dem zweiten Bestandsdatenbeschluss des BVerfG für die durch das Gesetz zur Bekämpfung des Rechtsextremismus und der Hasskriminalität geschaffenen Datenverarbeitungsregelungen, “ Opinion for the Green Party from September 16, 2020: 3.

31 Bundestag Drucksache 19/25294 (German Parliament Document).

32 Bundestag Drucksache 19/29392 (German Parliament Document).

33 Stefan Krempl, "NetzDG-Reform: Gesetzgeber verstrickt sich in unauflösbare Widersprüche," heise online, last modified June 17, 2020, https://www.heise.de/ne ws/NetzDG-Reform-Gesetzgeber-verstrickt-sich-in-unaufloesbare-Widersprueche-4 786964.html. 


\section{Out-of-court conciliation}

The Amending Act also contains a provision for the introduction of an out-of-court dispute resolution. This is intended to enable alternative dispute resolution on a low-key basis. The dispute resolution bodies are not required to have any special qualifications; the goal is merely to make a serious attempt to resolve disputes possible. The parties involved are to be made aware of this possibility after the complaint procedure and also the counter-proposal procedure have been carried out; it thus serves to settle a dispute at a rather late stage. Together with the regulated self-regulation, this represents an attempt by the legislator to also involve other actors from civil society in the issues of content management on social networks. It is unclear how such models will evolve. The state is using these approaches primarily for the purpose of dispelling the impression of state censorship, but also to limit the power of social networks.

\section{Outlook}

The NetzDG has already done pioneering work and paved the way for similar laws on content regulation. The amendment makes meaningful additions and will likely allow for better law enforcement on social networks. Of course, the NetzDG has the insurmountable shortcoming that it only applies to Germany, which generally puts obstacles in the way of law enforcement. The European Digital Services Act is intended to put a lid on this under EU law and set standards throughout the Union. ${ }^{34}$ Until then, the NetzDG fulfills its role as an experimental field; since Germany is also big enough to stand up to Facebook and Co. in some respects. So, here the famous saying from American constitutional law comes into play, that the states are the "laboratories" for the entire federal system. ${ }^{35}$ The NetzDG has made clear what kind of rules are to be found in such regulations. Complaint management is at the heart of this, and transparency regulations enable control by the state and the public. One lesson that Germany had to learn only in the course of application is the inclusion of the network's own deletion guidelines.

34 See chapter in this book Holznagel/Kalbhenn.

35 New State Ice Co. v. Liebmann, 285 U.S. 262, 311 (1932) (Brandeis, J., dissenting). 


\section{Bibliography}

Bäcker, Matthias. "Folgerungen aus dem zweiten Bestandsdatenbeschluss des BVerfG für die durch das Gesetz zur Bekämpfung des Rechtsextremismus und der Hasskriminalität geschaffenen Datenverarbeitungsregelungen." Opinion for the Green Party from September 16, 2020.

Eifert, Martin. "Rechenschaftspflichten für soziale Netzwerke und Suchmaschinen." Neue Juristische Wochenschrift (NJW) 2017, 1450-1454.

Facebook. "Community Standards Enforcement Report, Third Quarter 2020.” Accessed July 6, 2021. https://about.fb.com/news/2020/11/community-standards-en forcement-report-nov-2020/.

Facebook. "NetzDG Transparenzbericht Januar 2021." Accessed July 6, 2021. https://about.fb.com/de/wp-content/uploads/sites/10/2021/01/Facebook-Net zDG-Transparenzbericht-Januar-2021.pdf.

Federal Ministry of Justice and Consumer Protection. "Bundesamt für Justiz (BfJ) erlässt Bußgeldbescheid gegen Facebook.” Press release from July 3, 2019. Accessed July 6, 2021. https://www.bmjv.de/SharedDocs/Artikel/DE/2019/070319_ Facebook.html.

FSM. “NetzDG.” Accessed July 6, 2021. https://www.fsm.de/de/netzdg.

Gersdorf, Hubertus. "Hate Speech in sozialen Netzwerken." MMR Zeitschrift für IT-Recht und Recht der Digitalisierung (2017): 439-447.

Guggenberger, Nikolas. "Das Netzwerkdurchsetzungsgesetz - schön gedacht, schlecht gemacht.“ Zeitschrift für Rechtspolitik ZRP (2017): 98-101

Guggenberger, Nikolas. "Das Netzwerkdurchsetzungsgesetz in der Anwendung." Neue Juristische Wochenschrift (NJW) (2017): 2577-2582.

Heindorf, Manon. „Das Netzwerkdurchsetzungsgesetz in der Umsetzung: Zwei Jahre NetzDG - eine Bilanz." Verwaltungsrundschau VR (2020): 113-118.

Holznagel, Bernd. "Das Compliance-System des Entwurfs des Netzwerkdurchsetzungsgesetzes." Zeitschrift für Urheber- und Medienrecht ZUM (2017): 615-624.

Hoven, Elisa and Melena Krause. "Die Strafbarkeit der Verbreitung von ,Fake News“."Juristische Schulung (JuS) (2017): 1167-1170.

Krempl, Stefan. "NetzDG-Reform: Gesetzgeber verstrickt sich in unauflösbare Widersprüche." heise online. Last modified June 17, 2020. https://www.heise. de/news/NetzDG-Reform-Gesetzgeber-verstrickt-sich-in-unaufloesbare-Widerspr ueche-4786964.html.

Ladeur, Karl-Heinz. "Ist der Regierungsentwurf eines NetzDG 2.0 vom 19.2.2020 netzgerecht?" Kommunikation und Recht KÆR (2020): 248-253.

Löber, Lena Isabell and Alexander Roßnagel. "Das Netzwerkdurchsetzungsgesetz in der Umsetzung. "MMR (2019): 71-76.

Liesching, Marc, Chantal Funke, Alexander Hermann, Christian Kneschke, Carolin Michnik, Linh Nguyen, Johanna Prüßner, Sarah Rudolph, Vivien Zschammer. Das NetzDG in der praktischen Anwendung. Berlin: Carl Grossmann Verlag, 2021. doi:10.24921/2021.94115953. 
Niggemann, Sandra. "Die NetzDG-Novelle." Computer und Recht CR (2020): 326-331.

Peukert, Alexander. "Gewährleistung der Meinungs- und Informationsfreiheit in sozialen Netzwerken,“ MMR (2018): 572-578.

Schwartmann, Rolf. "Verantwortlichkeit Sozialer Netzwerke nach dem Netzwerkdurchsetzungsgesetz," GRUR-Prax Praxis im Immaterialgüter- und Wettbewerbsrecht (2017): 317-319.

Scientific service of the Bundestag. "Die Vereinbarkeit der Meldepflicht nach $₫ 3 a$ Abs. 4 NetzDG n.F. mit dem Recht der Sitzländer der Anbieter von sozialen Netzwerken und das Verhältnis der verschiedenen Einrichtungen der Entscheidungskontrolle nach NetzDG und JMStV." September 11, 2020 Document No. WD 10 - 3000 - 043/20.

Spindler, Gerald. "Der Regierungsentwurf zum Netzwerkdurchsetzungsgesetz - europarechtswidrig?" Zeitschrift für Urheber- und Medienrecht ZUM (2017): 473-487.

Wimmers, Jörg and Britta Heymann. "Zum Referentenentwurf eines Netzwerkdurchsetzungsgesetzes (NetzDG) - eine kritische Stellungnahme." AfP Zeitschrift für das gesamte Medienrecht (2017): 93-102. 